\title{
The Third Generation (UMTS) Spectrum Auction in Germany*
}

\author{
VERONIKA GRIMM FRANK RIEDEL ELMAR WOLFSTETTER \\ Institut f. Wirtschaftstheorie I, Humboldt Universität zu Berlin \\ Spandauer Str. 1, 10178 Berlin, Germany \\ E-mail: grimm/riedel/wolf@wiwi.hu-berlin.de
}

August 2001

\begin{abstract}
The third generation UMTS auction in Germany raised an enormous amount of revenue, and at the same time achieved a more competitive market structure than other UMTS auctions in Europe. The present paper explains the design of that auction, and presents a game theoretic explanation of observed events during the crucial phase of that auction, which have puzzled several observers. In addition, the paper evaluates the merit of the German UMTS auction design, relative to the English design, that was predominantly employed in Europe.
\end{abstract}

KEYWORDS: auctions, telecommunications, industrial organization, game theory.

JEL classifications: D43, D44, D45, H20, L13.

\footnotetext{
*The authors served as consultants to prepare bidding for one bidder at the German UMTS auction. Financial support for this research was received by the Deutsche Forschungsgemeinschaft, SFB 373 ("Quantifikation und Simulation Ökonomischer Prozesse"), Humboldt-Universität zu Berlin. We wish to thank Barry Allan, Winand Emons, Achim Wambach, Gerhard Illing, and seminar participants at the universities of Bern, Frankfurt, Graz, Kiel, München, Tübingen, the Berlin Internet Economics Workshop, and the CESifo workshop in Venice for useful comments.
} 


\section{Introduction}

In the year 2000 several European countries auctioned licenses for third generation (UMTS) mobile telecommunications, the new standard that is expected to revolutionize mobile communications. ${ }^{1}$ Among other benefits, UMTS offers enormously higher transmission rates (up to 200 times faster than the current GSM standard). This allows mobile phone operators to supply an abundance of new services, from virtual banking, credit card transactions, and information and booking services to fast inter- and intranet access, audio and video clips on demand, and video conferencing, that promise to surpass the quality of the most advanced fixed line telephony.

Building third generation networks and marketing, handling, and billing the new services is enormously costly. The UMTS technology works at a higher frequency than GSM (the current industry standard in Europe) to transmit and receive information; therefore, each base station has a much shorter range. Roughly, UMTS networks require 4-16 times as many base stations to manage a given data flow as the established GSM networks. More stations also raise health concerns about radio emissions, and objections against the littering of the environment with transmitters and radio masts.

Nevertheless, the auctioning of UMTS licenses generated an unsurpassed amount of revenue. The UK treasury alone earned $€ 37.5$ billion, and the German finance minister cashed in the record sum of $€ 50.8$ billion. However, in some countries the UMTS auctions were disappointing. Revenue was remarkably low in the Netherlands and in Italy, which has one of the most profitable mobile phone markets in Europe. And the year ended with a complete flop in Switzerland, where only four bidders showed up to bid for four licenses, and the regulator desperately though in vain tried to patch up last minute changes in auction rules. That anticlimax continued well into the year 2001, when the auction had to be called off in Belgium and Israel.

To put the German auction into perspective, Table 1 summarizes the European UMTS auctions in the year 2000 in chronological order. There, the first column states the country (a star indicates that the German auction design was applied; all other countries applied the English rules). The second column states the month(s) when the UMTS auction took place, the third the number of bidders, the fourth the number of licenses (when a range is given, a star indicates the final number of licenses), the fifth

\footnotetext{
${ }^{1}$ UMTS means Universal Mobile Telecommunications System; it was introduced by the International Telecommunications Union as part of the IMT-2000 family of third generation mobile standards.
} 
the number of incumbents, the sixth the revenue per population unit, and the last the revenue divided by the population units per license, which is a more meaningful performance measure.

\begin{tabular}{lccccrr}
\hline \hline Where & When & \# Bidders & \#Licenses & \#Incumb & $€ /$ Pop & $€ /$ (Pop/Lic) \\
\hline \hline UK & $03 / 04$ & 13 & 5 & 4 & 630 & 3.150 \\
Netherlands & 07 & $9 / 6$ & 5 & 5 & 170 & 850 \\
Germany* & $07 / 08$ & $12 / 7$ & $4-6^{*}$ & 4 & 615 & 3.690 \\
Italy & 10 & $8 / 6$ & 5 & 4 & 210 & 1.050 \\
Austria* & 10 & 6 & $4-6^{*}$ & 3 & 103 & 618 \\
Switzerland & $11 / 12$ & $10 / 4$ & 4 & 3 & 19 & 76 \\
\hline \hline
\end{tabular}

Table 1: UMTS Auctions in Europe in the Year 2000

In all third generation (UMTS) spectrum auctions in Europe the supply of spectrum was roughly the same. A total band of $2 \times 60 \mathrm{MHz}$ (paired) spectrum, ${ }^{2}$ plus some $20 \mathrm{MHz}$ of unpaired spectrum. Also, everybody employed the same simultaneous, ascending price auction format, which is well-known ever since the first successful spectrum auctions took place in the US.

However, there was one important broad difference: Whereas the English auctioned a fixed number of licenses, each prepackaged with fixed amounts of radio spectrum (and restricting bidders to bid on one license only), the German regulator broke down the supply of paired spectrum into identical blocks, and allowed bidders to aggregate spectrum blocks into a variable number of licenses, ranging from 4 to 6 licenses. With the exception of Austria, which followed the German example, all other European regulators copied the English design.

While the English design earned high praise, the competing German design was harshly criticized by JEHIEL AND MOLDOVANU [2000] and MOLDOVANU [2000a,b] as "an error with serious consequences". Essentially, it was claimed that, due to their cost advantage, the four incumbents would outbid all new entrants, and that "the auction would most likely lead to four licenses in the hands of the four incumbents". This verdict was echoed by KLEMPERER who made similar statements in press interviews.

However, the results of the auction proved these critics wrong. The UMTS auction in Germany resulted in a more competitive market structure than in other European countries - altogether 6 licenses were issued, of which two went to new entrants - , and yet earned the highest revenue.

\footnotetext{
${ }^{2}$ Spectrum is paired because one is used to send and the other to receive information. To see why this is important, just listen to radio communication in a taxi cab; there, only one party is able to speak, until the line is freed for the other party to respond.
} 
In Germany seven bidders competed for 12 blocks of paired spectrum which could be aggregated into either 4 or 5 or 6 licenses. Since a license had to include at least two blocks, the auction could not possibly end before one bidder quit the auction. That point was reached in round 126. Here, the auction could have ended, but only if all remaining six bidders had reduced their demand to two blocks each. However, all six bidders maintained a demand for three blocks.

As the auction continued, the small incumbents and new entrants reduced demand to two blocks, one after another. And so, effective round 147, the two major incumbents (Mannesmann and T-Mobil) found themselves at the crucial phase of the auction, where they alone had to decide whether to end the auction. The predicted four license outcome was already bygone; the choice was only one between either 5 or 6 licenses.

Both major incumbents chose to maintain a demand for three blocks in order to acquire a "large" license of $2 \times 15 \mathrm{MHz}$ (equal in size to the large licenses $A$ and $B$ in the UK) each. However, several rounds later they both aborted that attempt, and the auction ended with 6 "small" licenses, acquired by the four incumbents and two new entrants.

That outcome, and the preceding behavior during the crucial phase of the auction, has puzzled several observers. Indeed, JEHIEL AND MOLDOVANU [2001] describe it as "bizarre", and question whether it can be consistent with equilibrium. Similarly, KLEMPERER [2001, footn. 52] equates the aborted attempt to acquire large licenses and thereby crowd-out one bidder with allegedly irrational behavior of his father-in-law (who apparently tended to quit standing in line, if it moved slowly).

The present paper explains the rules of the German UMTS auction, gives an account of events, and attempts a rational reconstruction of the play observed during the crucial phase of the auction. We proceed as follows: Section 2 explains the auction rules; Section 3 gives a summary of events, Section 4 introduces key assumptions of our analysis, and Section 5 proposes a game theoretic explanation. Section 6 discusses the merit of the German auction design, and the paper closes with a summary and conclusions (Section 7).

\section{Auction Rules}

Late in the year 1999 the regulator proposed rules for the upcoming UMTS auction. These were subjected to a hearing process with industry representatives and subsequently changed. The first proposed rules stipulated some form of discrimination in favor of new entrants. However, 
on February 18, 2000 the regulator decreed an entirely new format that involves a sequence of two auctions, and excludes all forms of discrimination. The highlights of these rules are as follows. ${ }^{3}$

For sale were $2 \times 60 \mathrm{MHz}$ paired spectrum in the 1900-2025 MHz band. These were broken up into 12 identical, individual blocks of $2 \times 5 \mathrm{MHz}$ each, numbered 1 to 12 . In addition, the regulator offered five blocks of $1 \mathrm{MHz}$ unpaired spectrum also in the $2 \mathrm{GHz}$ range the utility of which was still somewhat dubious at the time of the auction, which is why we ignore them here.

The two auctions were simultaneous, open, and ascending. The first auction was dedicated to sell the paired spectrum and to determine who gets a license. The second auction was devoted to sell leftover paired spectrum, in case anything was leftover from the first auction, and to sell the unpaired spectrum. Participation in the second auction was restricted to those who survived the first auction.

In the first auction bidders were restricted to bid on "at least two" and "at most three" blocks. Any bidder who, at the end of the first auction, held either three or two high bids was assured a license, and permitted to participate in the second auction. Those who held less than two high bids were excluded from the auction, and relieved from any obligation, even if they held one high bid. ${ }^{4}$

In the second auction, the surviving bidders could only bid for at most one block, in the event anything was leftover from the first auction. Bidding for unpaired spectrum (which will be ignored here) was unrestricted.

Given these restrictions, the feasible number of licenses was between 0 and 6 , each endowed with 2 to 4 blocks. ${ }^{5}$ Ignoring unlikely events, the relevant outcomes were either 4 or 5 or 6 licenses, endowed with 2 to 3 blocks.

An activity rule stipulated that bidding rights had to be exercised or would be lost forever. Specifically, the number of bidding rights in round $n+1$ was equal to the number of blocks on which that bidder placed a bid or had already held a high bid in the previous round $n$. Therefore, once a bidder had reduced his demand to two blocks, he could never return to demand three.

In both auctions, only the high bids were made public after every round. Thus, bidders could not directly observe their rivals' bids, and did not

\footnotetext{
${ }^{3}$ The complete auction rules can be found in REGTP [2000].

${ }^{4}$ The rationale for the "at least two" restriction was that building a network of radio stations is not economically feasible with a capacity of only one block of radio spectrum.

${ }^{5}$ In order to acquire 4 blocks, a bidder would have to acquire 3 blocks in the first auction, and one leftover block in the second auction.
} 
know exactly their number of bidding rights. However, when only a few high bids change, it is possible to infer bidding rights, as we explain in Section 3.

The minimum bid was DM 100 million per block, and the minimum increment was $10 \%$. However, the regulator was free to change this, and he actually reduced it towards the end of the auction. If there were any leftover spectrum, the minimum bid was reset in the second auction to DM 100 million per block.

All blocks were "abstract" in the sense that bidders did not buy the right to obtain concrete spectrum, defined by a particular location within the $2 \mathrm{Ghz}$ band. Instead, the regulator made a pledge to assign the best allocation of spectrum, that minimizes interference, after the results of the auction are known. In principle, this intelligently eliminated the coordination problems that plagued earlier spectrum auctions in the US.

We close our account of the auction rules with some straightforward yet important implications:

1. There cannot be more than six licenses; therefore, the first auction cannot end before one of the seven bidders has quit.

2. When only six bidders are left, one bidder alone can force out one other bidder, by maintaining three bidding rights, thus driving up the prices of all licenses.

3. When only five bidders are left, one more bidder can only be forced out if at least three bidders maintain three bidding rights.

4. The second auction is potentially appealing, because the minimum bid for leftover blocks of paired spectrum is set back to DM 100 million, and rival bidders are already "jam-packed".

\section{Summary of Events}

The auction was scheduled to begin on July 31, 2000, and it lasted 173 rounds of bidding, until August 17, 2000. Initially 12 bidders registered to participate. However, one bidder was not approved by the regulator, and five bidders withdrew successively prior to the auction. As a result, only seven bidders showed up to bid for 4-6 licenses. These were the four incumbent mobile phone operators: T-Mobil (a subsidiary of Deutsche Telekom) (T), Mannesmann-Vodafone (M), e-plus (e+), and Viag 
Interkom (viag), backed by British Telecom, and three new entrants: $M o$ bilcom (mobi), backed by France Telecom, debitel (debi), backed by Swisscom, and $3 G$, backed by Telefonica and Sonera. ${ }^{6}$

Among the four incumbents, $\mathrm{M}$ and $\mathrm{T}$ each serve $40 \%$ of customers in the German mobile phone market, whereas e+ and viag have only a market share of $15 \%$ and 5\%, respectively. Among the new entrants, debi and mobi are already present in the market as service providers (with their own customers and billing system). Only G3 has no prior role in the market. However, the firms that back G3 were already strong and wellestablished European providers of mobile phone services. Also mobi has a strong backing, whereas debi did not succeed to find strong partners.

At the auction, bidding started cautiously. All bidders opened with the minimum bid, and then used small increments, except mobi, who started with a jump bid of DM 501 million on two blocks (see Table 2). It took 45 rounds until the other bidders caught up with that initial jump bid.

\begin{tabular}{|c|c|c|c|c|c|c|c|c|c|c|c|c|}
\hline \multirow[t]{2}{*}{$\overline{\overline{\text { Round }}}$} & \multicolumn{12}{|c|}{ Frequency Block } \\
\hline & 1 & 2 & 3 & 4 & 5 & 6 & 7 & 8 & 9 & 10 & 11 & 12 \\
\hline 1 & $\begin{array}{l}100 \\
T\end{array}$ & $\begin{array}{l}100 \\
T\end{array}$ & $\begin{array}{l}100 \\
T\end{array}$ & $\begin{array}{l}501 \\
m o b i\end{array}$ & $\begin{array}{l}501 \\
m o b i\end{array}$ & $\begin{array}{l}150 \\
M\end{array}$ & $\begin{array}{l}100 \\
3 G\end{array}$ & - & $\begin{array}{l}100 \\
e+\end{array}$ & - & - & - \\
\hline 2 & $\begin{array}{l}100 \\
T\end{array}$ & $\begin{array}{l}100 \\
T\end{array}$ & $\begin{array}{l}100 \\
T\end{array}$ & $\begin{array}{l}501 \\
m o b i\end{array}$ & $\begin{array}{l}501 \\
m o b i\end{array}$ & $\begin{array}{l}150 \\
M\end{array}$ & $\begin{array}{l}100 \\
3 G\end{array}$ & $\begin{array}{l}100 \\
\text { e+ }\end{array}$ & $\begin{array}{l}100 \\
\text { e+ }\end{array}$ & $\begin{array}{l}100 \\
\text { viag }\end{array}$ & $\begin{array}{l}150 \\
M\end{array}$ & $\begin{array}{l}150 \\
M\end{array}$ \\
\hline 3 & $\begin{array}{l}110 \\
3 G\end{array}$ & $\begin{array}{l}110 \\
3 G\end{array}$ & $\begin{array}{l}100 \\
T\end{array}$ & $\begin{array}{l}501 \\
m o b i\end{array}$ & $\begin{array}{l}501 \\
m o b i\end{array}$ & $\begin{array}{l}150 \\
M\end{array}$ & $\begin{array}{l}111 \\
\text { viag }\end{array}$ & $\begin{array}{l}111 \\
\text { viag }\end{array}$ & $\begin{array}{l}110 \\
\text { debi }\end{array}$ & $\begin{array}{l}100 \\
\text { viag }\end{array}$ & $\begin{array}{l}150 \\
M\end{array}$ & $\begin{array}{l}150 \\
M\end{array}$ \\
\hline
\end{tabular}

Table 2: Cautious Beginning (high bids per round in DM million)

From the high bids during subsequent rounds, it was clear that initially all bidders maintained three bidding rights. Thus, in the early rounds of the auction, total demand was 21 blocks, while supply was only twelve blocks.

As long as excess demand remains high, bidders cannot typically find out whether another bidder has reduced demand, since only high (and not all) bids were published. However, there are circumstances in which such an inference can be drawn beyond doubt. In particular, one can be sure that a rival bidder has reduced demand to two blocks if that bidder

- held no high bids in the previous round, and only two high bids have changed;

\footnotetext{
${ }^{6}$ The bidder who was not approved, due to insufficient funding and experience, was Nets AG; the bidders who withdrew prior to the auction were (in this order): Hutchison (who formed an alliance with e-plus and thus, had to back out), MCI Worldcom, Vivendi, and Talkline.
} 
- held one high bid in the previous round, and only one high bid other than his own has changed,

- held two high bids in the previous round, and only those bids have changed.

The first bidder who gave up one bidding right was debi. This was announced after day nine of the auction (round 115); however, the last round where debi was seen to have three high bids was round 70. All key events described in the remainder of this section are illustrated in Table $3 .^{7}$

The auction could not possibly end before one of the seven bidders quit the auction. This precondition was met when debi finally gave up, when price per block had reached roughly DM 5 billion (the announcement came at the end of day 10 (round 127)).

At this point, all remaining six bidders still maintained three bidding rights (except possibly viag). Therefore, the full range of market structures, either 4 of 5 or 6 licenses, was still within reach.

As the auction continued, all bidders, except the two major incumbents, reduced their demand to two blocks, one after another. Viag was last seen to have three high bids in round 110, and reduced demand not later than in round $134 .{ }^{8}$ 3G was seen to be active on three blocks until round 132, and reduced demand to two blocks not later than in round 138. Both demand reductions were announced after day 11 of the auction (round 138). On the following day, the auctioneer reduced the minimum increment from $10 \%$ to $5 \%$.

The last round where e+ and mobi had three high bids was 137 and 140, respectively. In rounds 140 and 146 e+ and mobi followed suit and reduced demand as well.

From this point on, it was no longer possible to end the auction with four licenses (recall: "it takes at least three bidders with three bidding rights to crowd out two more bidders"). It was also impossible to immediately terminate the auction with six licenses, since in round $146 \mathrm{M}$ held three high bids, while mobi only held one.

However, effective round 147, the two major incumbents, $\mathrm{M}$ and $\mathrm{T}$, found themselves at the crucial phase of the auction, where they alone had to

\footnotetext{
${ }^{7}$ We have compiled the high bids in all rounds in an excel file, and make this available for download at "http://www.wiwi.hu-berlin.de/wt1/papers/umts.zip". Unfortunately, the German regulator does not release information on all bids.

${ }^{8}$ In round 133 viag holds only one high bid, and in rounds 133 and 134 only the high bid on block 5 changes. Thus, one can infer that viag holds at most two bidding rights effective round 135 .
} 


\begin{tabular}{|c|c|c|c|c|c|c|c|c|c|c|c|c|}
\hline \multirow[t]{2}{*}{$\overline{\overline{\text { Round }}}$} & \multicolumn{12}{|c|}{ Frequency Block } \\
\hline & 1 & 2 & 3 & 4 & 5 & 6 & 7 & 8 & 9 & 10 & 11 & 12 \\
\hline \multicolumn{13}{|c|}{ Round 126: debitel exits } \\
\hline 125 & $\begin{array}{l}5117.2 \\
\text { et }\end{array}$ & $\begin{array}{l}5129.7 \\
\text { et }\end{array}$ & $\begin{array}{l}4989.0 \\
\text { et }\end{array}$ & $\begin{array}{l}4897.0 \\
\text { debi }\end{array}$ & $\begin{array}{l}4730.0 \\
\text { viag }\end{array}$ & $\begin{array}{l}4700.0 \\
\text { mobi }\end{array}$ & $\begin{array}{l}4880.0 \\
\text { mobi }\end{array}$ & $\begin{array}{l}4870.0 \\
\text { debi }\end{array}$ & $\begin{array}{l}4872.3 \\
M\end{array}$ & $\begin{array}{l}4992.1 \\
\text { viag }\end{array}$ & $\begin{array}{l}4947.2 \\
T\end{array}$ & $\begin{array}{l}4987.3 \\
M\end{array}$ \\
\hline 126 & $\begin{array}{l}5117.2 \\
\text { et }\end{array}$ & $\begin{array}{l}5129.7 \\
\text { et }\end{array}$ & $\begin{array}{l}4989.0 \\
\text { et }\end{array}$ & $\begin{array}{l}5400.0 \\
\text { mobi }\end{array}$ & $\begin{array}{l}5203.0 \\
3 G\end{array}$ & $\begin{array}{l}5200.0 \\
\text { mobi }\end{array}$ & $\begin{array}{l}5368.0 \\
T\end{array}$ & $\begin{array}{l}5357.0 \\
3 G\end{array}$ & $\begin{array}{l}4872.3 \\
M\end{array}$ & $\begin{array}{l}4992.1 \\
\text { viag }\end{array}$ & $\begin{array}{l}4947.2 \\
T\end{array}$ & $\begin{array}{l}4987.3 \\
M\end{array}$ \\
\hline \multicolumn{13}{|c|}{ Round 134: viag drops third bidding right } \\
\hline 133 & $\begin{array}{l}6200.0 \\
\text { mobi }\end{array}$ & $\begin{array}{l}6207.0 \\
\text { viag }\end{array}$ & $\begin{array}{l}6060.0 \\
3 G\end{array}$ & $\begin{array}{l}5940.0 \\
M\end{array}$ & $\begin{array}{l}5723.6 \\
M\end{array}$ & $\begin{array}{l}6296.6 \\
\text { M }\end{array}$ & $\begin{array}{l}6060.0 \\
3 G\end{array}$ & $\begin{array}{l}5892.7 \\
\text { e+ }\end{array}$ & $\begin{array}{l}5895.6 \\
T\end{array}$ & $\begin{array}{l}6040.6 \\
\text { e+ }\end{array}$ & $\begin{array}{l}6060.0 \\
T\end{array}$ & $\begin{array}{l}6050.0 \\
\text { mobi }\end{array}$ \\
\hline 134 & $\begin{array}{l}6200.0 \\
\text { mobi }\end{array}$ & $\begin{array}{l}6207.0 \\
\text { viag }\end{array}$ & $\begin{array}{l}6060.0 \\
3 G\end{array}$ & $\begin{array}{l}5940.0 \\
M\end{array}$ & $\begin{array}{l}6296.1 \\
\text { e+ }\end{array}$ & $\begin{array}{l}6296.6 \\
M\end{array}$ & $\begin{array}{l}6060.0 \\
3 G\end{array}$ & $\begin{array}{l}5892.7 \\
e+\end{array}$ & $\begin{array}{l}5895.6 \\
T\end{array}$ & $\begin{array}{l}6040.6 \\
e+\end{array}$ & $\begin{array}{l}6060.0 \\
T\end{array}$ & $\begin{array}{l}6050.0 \\
\text { mobi }\end{array}$ \\
\hline \multicolumn{13}{|c|}{ Round 138: 3G drops third bidding right; } \\
\hline 137 & $\begin{array}{l}6200.0 \\
\text { mobi }\end{array}$ & $\begin{array}{l}6207.0 \\
\text { viag }\end{array}$ & $\begin{array}{l}6060.0 \\
3 G\end{array}$ & $\begin{array}{l}6666.0 \\
T\end{array}$ & $\begin{array}{l}6296.1 \\
\text { e+ }\end{array}$ & $\begin{array}{l}6296.6 \\
M\end{array}$ & $\begin{array}{l}6666.0 \\
\mathrm{~T}\end{array}$ & $\begin{array}{l}6482.0 \\
\text { mobi }\end{array}$ & $\begin{array}{l}6485.3 \\
\text { e+ }\end{array}$ & $\begin{array}{l}6644.7 \\
\text { viag }\end{array}$ & $\begin{array}{l}6060.0 \\
T\end{array}$ & $\begin{array}{l}6666.0 \\
M\end{array}$ \\
\hline 138 & $\begin{array}{l}6200.0 \\
\text { mobi }\end{array}$ & $\begin{array}{l}6207.0 \\
\text { viag }\end{array}$ & $\begin{array}{l}6696.0 \\
3 G\end{array}$ & $\begin{array}{l}6666.0 \\
T\end{array}$ & $\begin{array}{l}6296.1 \\
\text { e+ }\end{array}$ & $\begin{array}{l}6296.6 \\
M\end{array}$ & $\begin{array}{l}6666.0 \\
\mathrm{~T}\end{array}$ & $\begin{array}{l}6482.0 \\
\text { mobi }\end{array}$ & $\begin{array}{l}6485.3 \\
\text { e+ }\end{array}$ & $\begin{array}{l}6644.7 \\
\text { viag }\end{array}$ & $\begin{array}{l}6696.0 \\
3 G\end{array}$ & $\begin{array}{l}6666.0 \\
M\end{array}$ \\
\hline 139 & $\begin{array}{l}6510.0 \\
T\end{array}$ & $\begin{array}{l}6517.4 \\
\text { mobi }\end{array}$ & $\begin{array}{l}6696.0 \\
3 G\end{array}$ & $\begin{array}{l}6666.0 \\
T\end{array}$ & $\begin{array}{l}6296.1 \\
\text { et }\end{array}$ & $\begin{array}{l}6296.6 \\
M\end{array}$ & $\begin{array}{l}6666.0 \\
T\end{array}$ & $\begin{array}{l}6482.0 \\
\text { mobi }\end{array}$ & $\begin{array}{l}6485.3 \\
\text { e+ }\end{array}$ & $\begin{array}{l}6644.7 \\
\text { viag }\end{array}$ & $\begin{array}{l}6696.0 \\
3 G\end{array}$ & $\begin{array}{l}6666.0 \\
M\end{array}$ \\
\hline 140 & $\begin{array}{l}6510.0 \\
T\end{array}$ & $\begin{array}{l}6517.4 \\
\text { mobi }\end{array}$ & $\begin{array}{l}6696.0 \\
3 G\end{array}$ & $\begin{array}{l}6666.0 \\
T\end{array}$ & $\begin{array}{l}6611.1 \\
\text { et }\end{array}$ & $\begin{array}{l}6296.6 \\
M\end{array}$ & $\begin{array}{l}6666.0 \\
T\end{array}$ & $\begin{array}{l}6482.0 \\
\text { mobi }\end{array}$ & $\begin{array}{l}6485.3 \\
\text { e+ }\end{array}$ & $\begin{array}{l}6644.7 \\
\text { viag }\end{array}$ & $\begin{array}{l}6696.0 \\
3 G\end{array}$ & $\begin{array}{l}6666.0 \\
M\end{array}$ \\
\hline
\end{tabular}

Round 146: Mobilcom drops third bidding right

\begin{tabular}{|c|c|c|c|c|c|c|c|c|c|c|c|c|}
\hline 145 & $\begin{array}{l}6835.5 \\
M\end{array}$ & $\begin{array}{l}6843.6 \\
M\end{array}$ & $\begin{array}{l}6696.0 \\
3 G\end{array}$ & $\begin{array}{l}6666.0 \\
\mathrm{~T}\end{array}$ & $\begin{array}{l}6941.8 \\
\text { et }\end{array}$ & $\begin{array}{l}6950.0 \\
\text { mobi }\end{array}$ & $\begin{array}{l}6999.4 \\
\text { viag }\end{array}$ & $\begin{array}{l}7146.6 \\
\text { M }\end{array}$ & $\begin{array}{l}6809.7 \\
\text { e+ }\end{array}$ & $\begin{array}{l}6644.7 \\
\text { viag }\end{array}$ & $\begin{array}{l}6696.0 \\
3 G\end{array}$ & $\begin{array}{l}6999.5 \\
T\end{array}$ \\
\hline 146 & $\begin{array}{l}6835.5 \\
M\end{array}$ & $\begin{array}{l}6843.6 \\
M\end{array}$ & $\begin{array}{l}6696.0 \\
3 G\end{array}$ & $\begin{array}{l}6999.6 \\
\text { mobi }\end{array}$ & $\begin{array}{l}6941.8 \\
\text { e+ }\end{array}$ & $\begin{array}{l}7297.5 \\
T\end{array}$ & $\begin{array}{l}6999.4 \\
\text { viag }\end{array}$ & $\begin{array}{l}7146.6 \\
M\end{array}$ & $\begin{array}{l}6809.7 \\
\text { e+ }\end{array}$ & $\begin{array}{l}6644.7 \\
\text { viag }\end{array}$ & $\begin{array}{l}6696.0 \\
3 G\end{array}$ & $\begin{array}{l}6999.5 \\
T\end{array}$ \\
\hline 147 & $\begin{array}{l}6835.5 \\
M\end{array}$ & $\begin{array}{l}6843.6 \\
M\end{array}$ & $\begin{array}{l}6696.0 \\
3 G\end{array}$ & $\begin{array}{l}6999.6 \\
\text { mobi }\end{array}$ & $\begin{array}{l}6941.8 \\
\text { e+ }\end{array}$ & $\begin{array}{l}7297.5 \\
T\end{array}$ & $\begin{array}{l}6999.4 \\
\text { viag }\end{array}$ & $\begin{array}{l}7146.6 \\
M\end{array}$ & $\begin{array}{l}6809.7 \\
e+\end{array}$ & $\begin{array}{l}7001.7 \\
T\end{array}$ & $\begin{array}{l}6696.0 \\
3 G\end{array}$ & $\begin{array}{l}6999.5 \\
T\end{array}$ \\
\hline
\end{tabular}

Round 167: Telekom drops third bidding right

\begin{tabular}{|c|c|c|c|c|c|c|c|c|c|c|c|c|}
\hline 166 & $\begin{array}{l}7914.5 \\
\text { viag }\end{array}$ & $\begin{array}{l}7930.0 \\
\text { mobi }\end{array}$ & $\begin{array}{l}7777.7 \\
T\end{array}$ & $\begin{array}{l}8141.7 \\
M\end{array}$ & $\begin{array}{l}8036.9 \\
\text { viag }\end{array}$ & $\begin{array}{l}8045.6 \\
M\end{array}$ & $\begin{array}{l}8141.4 \\
3 G\end{array}$ & $\begin{array}{l}8274.3 \\
\text { e+ }\end{array}$ & $\begin{array}{l}7883.7 \\
\text { mobi }\end{array}$ & $\begin{array}{l}8143.9 \\
\text { et }\end{array}$ & $\begin{array}{l}8143.8 \\
M\end{array}$ & $\begin{array}{l}8141.4 \\
3 G\end{array}$ \\
\hline 167 & $\begin{array}{l}8310.4 \\
\text { viag }\end{array}$ & $\begin{array}{l}7930.0 \\
\text { mobi }\end{array}$ & $\begin{array}{l}8166.6 \\
T\end{array}$ & $\begin{array}{l}8141.7 \\
M\end{array}$ & $\begin{array}{l}8036.9 \\
\text { viag }\end{array}$ & $\begin{array}{l}8045.6 \\
M\end{array}$ & $\begin{array}{l}8141.4 \\
3 G\end{array}$ & $\begin{array}{l}8274.3 \\
\text { e+ }\end{array}$ & $\begin{array}{l}8277.9 \\
T\end{array}$ & $\begin{array}{l}8143.9 \\
\text { et }\end{array}$ & $\begin{array}{l}8143.8 \\
M\end{array}$ & $\begin{array}{l}8141.4 \\
3 G\end{array}$ \\
\hline \multicolumn{13}{|c|}{ Round 173: Final allocation } \\
\hline 173 & $\begin{array}{l}8310.4 \\
\text { viag }\end{array}$ & $\begin{array}{l}8170.0 \\
\text { mobi }\end{array}$ & $\begin{array}{l}8330.0 \\
M\end{array}$ & $\begin{array}{l}8304.6 \\
3 G\end{array}$ & $\begin{array}{l}8200.0 \\
\text { mobi }\end{array}$ & $\begin{array}{l}8206.6 \\
\text { viag }\end{array}$ & $\begin{array}{l}8304.3 \\
T\end{array}$ & $\begin{array}{l}8274.3 \\
\text { et }\end{array}$ & $\begin{array}{l}8277.9 \\
T\end{array}$ & $\begin{array}{l}8143.9 \\
\text { et }\end{array}$ & $\begin{array}{l}8143.8 \\
M\end{array}$ & $\begin{array}{l}8141.4 \\
3 G\end{array}$ \\
\hline
\end{tabular}

Table 3: Summary of Demand Reductions (high bids in DM million) 
decide whether to end the auction or maintain a demand for three blocks, and thus continue the attempt to crowd out one more bidder from the auction. They both chose to maintain a demand for three blocks, but when it turned out that they had not succeeded to crowd out one more bidder after many more rounds of increasingly costly bidding, T reduced its demand to two packages in round 167, and $M$ followed suit in round 172.

And so the auction ended in round 173 with six "small" $(2 \times 10 \mathrm{MHz})$ licenses, acquired by the four incumbents, and the two new entrants: mobi and 3G. The price per block was roughly DM 8 billion, and total auction revenue DM 98,807.2 million. Since no paired blocks were left over, in the second auction only unpaired spectrum was sold. There, each licensee, except viag, got one block, adding DM 561 million to the auction revenue.

As in other spectrum auctions, bidders occasionally used the last digits of feasible bids (the smallest money unit was DM 100.000) to signal their intentions or to attempt a coordination of actions. Such coordination can be useful to determine who shall get which block if excess demand has vanished, and, perhaps, to suggest to other bidders that bidding may come to a quick end if they reduce their demand.

It has been claimed that such signalling occurred already before the crucial phase of the auction, in rounds 133 to 146. Indeed, in these rounds one observes an abundance of the digit 6 , wich we indicate by bold faced entries in Table 3, and which cannot be explained by the minimum increment requirement. If it is correct to interpret these bids as signals, one would conclude that bidders $\mathrm{M}, \mathrm{T}$, and $3 \mathrm{G}$ signalled that they would be willing to settle with a market structure of 6 licenses. However, one should probably only consider those bids, if any, where the 6 occurred in the last digit, because it is hard to believe that bidders would waste millions and more to convey a signal of dubious value.

An unequivocal case of signalling occurred during and shortly before the crucial phase of the auction. During the rounds 130 to 150, M sent the signal " 6 " in seven out of eight of their visible new (high) bids, indicating that they would settle with a market structure of 6 licenses. During rounds 130 to 140, T repeatedly sent the same signal. However, on two occasions, in rounds 144 and 146 they used a " 5 " as the last digit of their high bids (while bidding higher than the required increment). This has been interpreted to mean that $\mathrm{T}$ indicated to $\mathrm{M}$ that they do not consent to a market structure of 6 licenses, and instead suggest to continue the attempt to crowd out another bidder. ${ }^{9}$ However, this interpretation

\footnotetext{
${ }^{9}$ See JEHIEL AND MOLDOVANU [2001], who suspect that T may have driven up prices in the interest of its majority shareholder, the Germany government.
} 
is not entirely convincing, on several grounds. First of all, T obviously sent contradictory signals, if their actions were signals at all. Second, M continued the attempt to crowd out one more bidder even after $\mathrm{T}$ had already reduced its demand to two blocks. And third, it is not clear why $\mathrm{T}$ should convince $\mathrm{M}$ to maintain a demand for three blocks, since it did not require any coordinated effort to crowd out one more bidder, by the "one is enough to crowd out one bidder" principle.

\section{Basic Assumptions}

To prepare the game theoretic analysis of the crucial phase of the UMTS auction in Germany, we now introduce some assumptions and notation. These are geared to the analysis of the relevant subgames, and they use some characteristics of the participating bidders, and the German mobile phone market.

Specifically, we assume that bidders have some idea of the ranking of bidders' valuations, have a preference for a less competitive market structure, which reflect in valuations that depend on the number of licenses, and are subject to incomplete information. In addition, we allow for stochastic dependencies, due to some form of affiliation between valuations.

At the given auction rules, a license is endowed with at least two and at most four blocks. Therefore, the marginal valuations for two, three, and four blocks matter. We denote the marginal valuations of bidder $i$ for each of the first two blocks by $V_{i}$, and those for the third and fourth block by $V_{i 3}, V_{i 4}$, respectively. Capital letters $V_{i}, V_{i j}$ denote random variables, small letters $v_{i}, v_{i j}$ realizations. Marginal valuations are not increasing.

Bidders have some common beliefs about each other's relative strength. In particular, the two major incumbents, $\mathrm{M}$ and $\mathrm{T}$, are viewed as considerably stronger and as identical. The weaker bidders are ranked by their strength (in this order) and called bidders 3 to 7 . In the industry, one had a pretty clear understanding of the ranking of their marginal valuations.

Specifically, we assume that for all states in the world

$$
\begin{gathered}
v_{M}=v_{T}>\max \left\{v_{3}, \ldots, v_{7}\right\} \\
v_{M 3}=v_{T 3}>v_{33} \geq \ldots \geq v_{73} \\
v_{M 4}=v_{T 4}
\end{gathered}
$$

A bidder's total valuation for 2 and 3 blocks is denoted by $w_{i}, w_{i 3}$ respectively:

$$
w_{i}:=2 v_{i}, \quad w_{i 3}:=w_{i}+v_{i 3}
$$


All these valuations $v, w$ are defined for a mobile phone market with six licenses, which is used as a reference point. Of course, bidders prefer to operate in a market with fewer competitors. We capture this by assuming that successful bidders earn higher valuations, represented by a bonus $b>0$, which applies if the number of licenses is reduced from six to five. ${ }^{10}$

In order to capture the uncertainty concerning the marginal valuation of the weakest among six bidders (called bidder 6), which plays a pivotal role, we assume that $V_{6}$ has two possible realizations (weak and strong): $V_{6} \in\left\{v_{6}, v_{6}^{\prime}\right\}$, with $v_{6}^{\prime}>v_{6}$, and $0<\operatorname{Pr}\left\{V_{6}=v_{6}\right\}=: \rho_{6}<1$.

At some stage in the auction game, the only new information that becomes available to the relevant players is the fact that bidder 6 is strong. Since we allow for stochastically dependent valuations, in this case we assume that bidders update their valuations. We capture this updating by denoting valuations conditional on $V_{6}=v_{6}^{\prime}$ by primed $v^{\prime} s$ and $w^{\prime} s$. The valuations that are conditional on $V_{6}=v_{6}$ are denoted by the $v^{\prime} s$ and $w^{\prime} s$ without primes. We assume $v^{\prime} \geq v, w^{\prime} \geq w$, and that the stochastic ordering (1) is preserved. Expected values of $v$ and $w$ are denoted by $\bar{v}:=v^{\prime}-\rho_{6}\left(v^{\prime}-v\right)$ and $\bar{w}:=w^{\prime}-\rho_{6}\left(w^{\prime}-w\right)$, respectively. Of course, our analysis permits, but does not require, stochastically dependent valuations.

An important detail of the German UMTS auction, that plays a key role in understanding events, is the fact that any blocks that are leftover in the first auction, are auctioned in the second auction. There, the minimum bid is set back to DM 100 million, only those who bought at least two blocks in the first auction are permitted to participate, and participants can only bid on one leftover spectrum. The latter implies that the second auction has all the essential features of a single-unit auction (see WEBER [1983]), and therefore is easily predictable. In particular, truthful bidding is a (weakly) dominant strategy in that second auction. It follows immediately that if one player, say $\mathrm{T}$, has acquired three blocks in the first auction, while all other five licensees have acquired only two blocks, one block is leftover, and player $\mathrm{M}$ will win it in the second auction, and pay a price equal to

$$
P_{2}:=\max \left\{V_{T 4}, V_{33}\right\}
$$

Of course, if the price in the first auction is already sky-high, it may be very appealing for player $\mathrm{M}$ to make sure that one block is leftover, and becomes relatively low-cost "prey" in the second auction, whenever that player has a chance to do so.

\footnotetext{
${ }^{10}$ We do not make assumptions concerning a market with four licenses, because this outcome could not have occurred in the phase of the game that we study here.
} 


\section{Game Theoretic Explanation}

We now analyze the crucial phase of the game, from round 148 onward. At that point only two of the remaining six bidders - the two dominant incumbents: $\mathrm{M}$ and $\mathrm{T}$ - have three bidding rights left. The only feasible market size is either five or six licenses; a four licenses outcome is already bygone. $\mathrm{M}$ and $\mathrm{T}$ can now also reduce demand to two blocks, and thus end the auction with a market size of six licenses, or attempt to crowdout one more bidder. Predation succeeds if $\mathrm{M}$ or T maintain(s) a demand for three blocks, until bidder 6 quits the auction, by the "one bidder alone can force out bidder 6" principle.

As we already pointed out in Section 3, in the actual course of events during that phase of the auction, both $\mathrm{M}$ and $\mathrm{T}$ attempted predation. However, at round $167 \mathrm{~T}$ reduced demand to two blocks, $\mathrm{M}$ followed some rounds later, and the auction ended in round 173 with 6 licenses. The goal of our analysis is to find necessary and sufficient conditions to explain the observed play as a perfect equilibrium, and to assess the plausibility of this explanation.

At this phase of the game the only strategic players are $\mathrm{M}$ and $\mathrm{T}$. The other remaining bidders have the weakly dominant strategy to maintain two bidding rights as long as the price for two blocks is below their valuation. Also, only the valuation of the weakest of the remaining bidders (which is bidder 6) is relevant for the strategic decisions of $\mathrm{M}$ and $\mathrm{T}$. Therefore, we can view this situation as a game played between the two strong bidders, $\mathrm{M}$ and $\mathrm{T}$, taking the behavior of bidders 3 to 6 as given, yet facing significant uncertainty about the valuation of the weakest remaining bidder.

In the following, we slightly simplify the remaining first auction game by condensing it to a two stage game. In the first stage, bidders $M$ and $T$ simultaneously choose either the action "r(esign)" (reduce demand to two blocks, immediately) or the action "t(ry predation)" by bidding prices up to the level $v_{6}$. The auction ends immediately, at the current price $p$, if both $\mathrm{M}$ and $\mathrm{T}$ play $\mathrm{r}$. If $\mathrm{M}$ or $\mathrm{T}$ plays $\mathrm{t}$, prices go up to the level $v_{6}$. At this point bidder 6 quits and the auction ends with a market size of 5 licenses in the event when bidder 6 is weak $\left(V_{6}=v_{6}\right)$. Whereas if bidder 6 is strong $\left(V_{6}=v_{6}^{\prime}\right)$, the game enters into the second stage. At this stage, valuations are common knowledge because it is clear by exclusion that bidder 6 is strong. Bidders who played "t" now have the choice between the actions "pr(edation)" (drive up prices further to the level $v_{6}^{\prime}$ ) and "r(esign)" (reduce demand to two blocks immediately). If $\mathrm{M}$ or T plays pr, prices go up to the level $v_{6}^{\prime}$, at which point bidder 6 quits, and a market size of five licenses is reached. 
When predation has succeeded, but either $\mathrm{M}$ or $\mathrm{T}$ has reduced demand to two blocks, one block is leftover. ${ }^{11}$ That leftover block is then sold in the second auction, and, given our assumptions, it will be acquired by the one dominant bidder who had reduced demand in the first auction, at the expected price $p_{2}:=E\left[\max \left\{V_{14}, V_{33}\right\} \mid V_{6}=v_{6}\right]$, if bidder 6 is weak, and $p_{2}^{\prime}:=E\left[\max \left\{V_{14}^{\prime}, V_{33}^{\prime}\right\} \mid V_{6}=v_{6}^{\prime}\right]$ if bidder 6 is strong, respectively.

The game tree of the first auction is depicted in Figure 1.

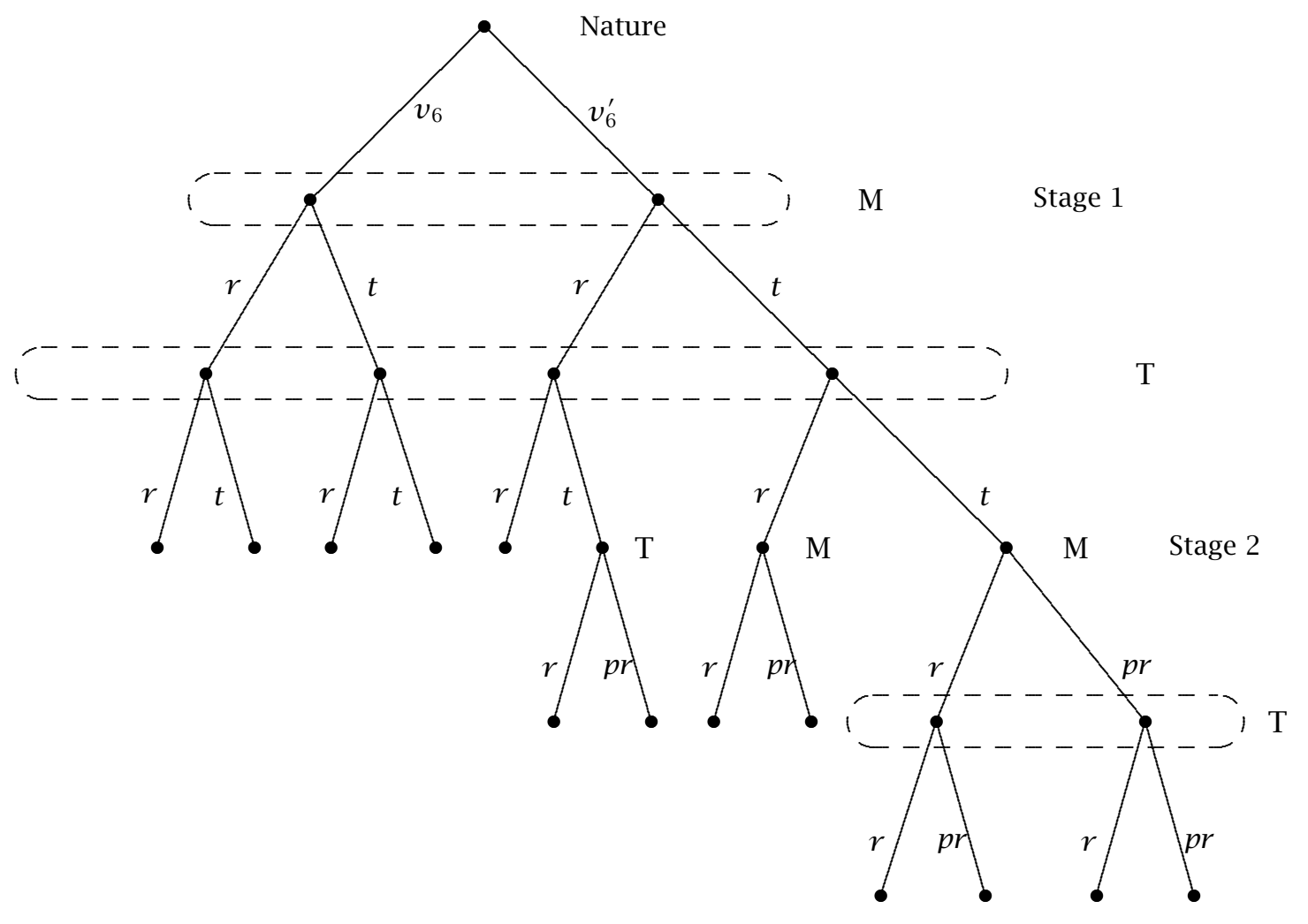

Figure 1: Game tree of the crucial phase of the UMTS auction

A strategy for a player is given by three actions at the three information sets in which the player has to move. So, the strategy $(t, r, p r)$ of player $\mathrm{M}$ means that he maintains three bidding rights in the first stage, reduces demand in stage 2 if the other player has reduced demand in stage 1 , and maintains three bidding rights in stage 2 if the other player has also maintained three bidding rights in stage 1.

The payoffs are as follows. If both $M$ and $T$ play $r$ in stage 1 , their payoff is $\bar{w}_{12}-2 p$, where $p$ denotes the current price, at the beginning of stage

\footnotetext{
${ }^{11} 4 \times 2$ plus $1 \times 2$ makes 11 blocks; since 12 blocks are available, one is left over.
} 
1. If one bidder has played $t$ and bidder 6 is weak, then bidder 6 quits, and prices are equal to $v_{6}$. The bidder who played $t$ earns the payoff $w_{13}+b-3 v_{6}$, and the bidder who played $r$ gets two blocks in the first auction and a third block in the second auction, at the expected price $p_{2}$; his payoff is thus $w_{13}+b-2 v_{6}-p_{2}$.

If at least one bidder plays $t$ and bidder 6 happens to be strong, the game continues. If one bidder has reduced demand, the other bidder has the option to crowd-out bidder 6 by increasing prices up to $v_{6}^{\prime}$ or to give up. If he gives up, both bidders obtain $w_{12}^{\prime}-2 v_{6}$. Otherwise, he gets $w_{13}^{\prime}+$ $b-3 v_{6}^{\prime}$, whereas the other bidder obtains the payoff $w_{13}^{\prime}+b-2 v_{6}^{\prime}-p_{2}^{\prime}$. If both bidders have maintained three bidding rights, we are in a subgame with complete information in which both players can choose two actions. The payoffs of bidder $\mathrm{M}$ are summarized in table 4 , where $\Delta_{p r}^{2}$ denotes the gain from unilateral predation, and $\Delta_{f r}^{2}$ the gain from "free riding" (playing $r$ while the rival plays $p r$ ).

We begin the analysis with the stage 2 subgames which are reached if at least one bidder has tried predation, but player 6 has not quit, because he happens to be strong. When these subgames are played, prices are already at the level $v_{6}$, and it is common knowledge that bidder 6 is strong $\left(V_{6}=v_{6}^{\prime}\right)$. Since the valuations of bidders 3 to 5 do not matter, it follows that these games can be viewed as games of complete information.

LEMMA 1 Consider all stage 2 subgames. Demand reduction is an equilibrium of these subgames iff "unilateral predation" does not pay:

$$
\Delta_{p r}^{2}:=v_{13}^{\prime}+b-\left(3 v_{6}^{\prime}-2 v_{6}\right) \leq 0
$$

That equilibrium is unique iff the inequality (6) is strict and, in addition, "free riding" pays:

$$
\Delta_{f r}^{2}:=v_{6}^{\prime}-p_{2}^{\prime}>0
$$

PROOF In a first step consider the particular stage 2 subgame in which both $\mathrm{M}$ and $\mathrm{T}$ have three bidding rights. Its payoff matrix is given in Table 4 . From this one can see immediately that $(r, r)$ is an equilibrium iff unilateral predation (playing $p r$ while the rival plays $r$ ) does not pay, i.e. iff $\Delta_{p r}^{2} \leq 0$. If the latter inequality is strict, $(r, p r)$ cannot also be an equilibrium. This leaves only $(p r, p r)$ as another candidate for an equilibrium. However, if the rival plays $p r$, playing $r$ entails that one block is leftover and acquired in the second auction at the expected price $p_{2}$. Evidently, such "free riding" on predation pays iff a third block is cheaper in the second than in the first auction, i.e. iff $\Delta_{f r}^{2}>0$.

Now, consider those stage 2 subgames in which only one of the two players has three bidding rights. Evidently, if $\Delta_{p r}^{2} \leq 0$, it is optimal for that 


\begin{tabular}{r|cc}
\hline \hline & \multicolumn{2}{|c}{ Bidder 2(T) } \\
& \multicolumn{1}{|c}{$p r$} \\
\hline Bidder 1 (M) & $\left(w_{12}^{\prime}-2 v_{6}\right)$ & {$[\ldots]+\Delta_{f r}^{2}$} \\
$p r$ & $(\ldots)+\Delta_{p r}^{2}$ & {$\left[w_{13}^{\prime}+b-3 v_{6}^{\prime}\right]$} \\
\hline \hline
\end{tabular}

Table 4: Payoff Matrix of Stage 2 Subgame

bidder to also reduce demand. If that inequality is strict, this is the unique optimal decision.

Note, if these conditions for uniqueness of equilibrium are satisfied, $r$ is actually a dominant strategy in all stage 2 subgames.

Using these results we arrive at the following necessary and sufficient conditions for existence and uniqueness of a subgame perfect equilibrium that conforms with the observed pattern of behavior.

THEOREM 1 The strategies $(t, r, r)$ for both players are a subgame perfect equilibrium iff free riding does not pay in stage 1:

$$
\Delta_{f r}^{1}:=\rho_{6}\left(v_{6}-p_{2}\right) \leq 0
$$

and $\Delta_{p r}^{2} \leq 0$ (unilateral predation does not pay in the stage 2 subgame).

That subgame perfect equilibrium is unique iff the inequality concerning $\Delta_{f r}^{1}$ is strict, unilaterally trying predation pays:

$$
\Delta_{t}^{1}:=\rho_{6}\left(v_{13}+b-v_{6}\right)-2\left(v_{6}-p\right)>0,
$$

and $\Delta_{p r}^{2}<0, \Delta_{f r}^{2}>0$ ( $r$ is a dominant strategy in all stage 2 subgames).

Proof The payoff matrix for bidder $\mathrm{M}$ of the reduced game in stage 1 is given in Table 5, assuming that $r$ is played in all stage 2 subgames by both $\mathrm{M}$ and T. There, the gain from free riding on predation (playing $r$ while the rival plays $t)$ is $\Delta_{f r}^{1}=\rho_{6}\left(v_{6}-p_{2}\right)$ because one gets a third block, at the expected price $p_{2}$, in the second auction only in the event when bidder 6 is weak. Similarly, the gain from unilaterally trying predation (playing $t$ while the rival plays $r$ in stage 1$)$ is $\Delta_{t}^{1}=\rho_{6}\left(v_{13}+b-v_{6}\right)-2\left(v_{6}-p\right)$, because one obtains a third block at the higher price $v_{6}$ when the sixth bidder is weak, and incurs the cost of raising prices to the level $v_{6}$, with no benefit, in the event when bidder 6 is strong.

By Lemma 1 it is known that $r$ is an equilibrium strategy in stage 2 if $\Delta_{p r}^{2} \leq 0$. Therefore, Table 5 applies, and it follows immediately that $(t, r, r)$ is an equilibrium iff $\Delta_{f r}^{1} \leq 0$ and $\Delta_{p r}^{2} \leq 0$. 


\begin{tabular}{r|cc}
\hline \hline & \multicolumn{1}{c}{ Bidder 2(T) } \\
\hline Bidder 1 (M) & $\left(\bar{w}_{12}-2 p\right)$ & $t$ \\
$t$ & $(\ldots)+\Delta_{t}^{1}$ & {$[\ldots]+\Delta_{f r}^{1}$} \\
\hline \hline
\end{tabular}

Table 5: Reduced Form Payoff Matrix of Stage 1 Subgame

The stronger conditions assure uniqueness of equilibrium in all stage 2 subgames, and uniqueness of equilibrium in the stage 1 reduced form game represented by Table 5 .

Is this rational "reconstruction" of the observed events in the German UMTS auction plausible?

A first objection might be that bidders do not engage in such complicated strategic reasoning as required in the above model. After all, why should they not bid in a straightforward way up to their valuation as in an ascending single unit auction? Now, one must note that such straightforward bidding is an ambiguous thing in the present multi-unit framework because the valuation of the bidders depends on the final number of licenses. So, keeping three bidding rights up to $v_{13}+b$, e.g., can easily lead to a winner's curse problem in case the attempted predation is not successful. On the other hand, keeping three bidding rights just up to $v_{13}$ is also not convincing because one does get the bonus if one gets three blocks. So, already the definition of straightforward bidding leads to 'complicated' reasoning.

Moreover, there is by now ample theoretical evidence that straightforward bidding need not be an equilibrium in multi-unit auctions because bidders have an incentive to strategically reduce demand in order to keep prices low. ${ }^{12}$ In any case, straightforward bidding is not a weakly dominant strategy, which it is in the single unit case.

Finally, $\mathrm{M}$ and $\mathrm{T}$ have already shown during the German GSM auction in 1999 that they understand very well the strategic issues of such auctions. There, M first outbid the two weaker bidders, and then equally shared the 10 blocks with $\mathrm{T}$, without further driving up prices (see our account of these events in GRIMM ET AL. [2001], where we also show that this play is the unique perfect equilibrium of that game).

Summing up, there is strong evidence that $\mathrm{M}$ and $\mathrm{T}$ did not use straightforward bidding.

\footnotetext{
${ }^{12}$ See Ausubel AND Schwartz [1999], MENEzes [1996], GRIMM, RIEDEL, AND WolFSTETTER [2001], ENGELBRECHT-WIGGANS AND KAHN [1998].
} 
Given that $\mathrm{M}$ and $\mathrm{T}$ behaved strategically, one may ask whether the conditions which are necessary to explain the observed behavior are plausible. When $\mathrm{M}$ and $\mathrm{T}$ give up the attempted predation, the (conditional expected) valuation of the sixth bidder must be relatively high compared to the bonus from predation and the additional value of a third block. This seems plausible since prices had already reached a high level when $\mathrm{M}$ and $\mathrm{T}$ gave up.

Ex ante, it must have been worth trying predation for $\mathrm{M}$ and $\mathrm{T}$. A necessary condition for this is that there was no incentive for free riding, that is, no incentive to reduce bidding rights to two and let the other player attempt predation. This means that the expected price $p_{2}$ of a block in the second round is higher than the valuation of a weak bidder 6 . Now, under which conditions is $p_{2}$ high? Since it is determined by the maximum of $V_{14}$ and $V_{33}$, either the valuation for a fourth block must be high for $M$ and $T$, or the valuation for a third block must be high for the third bidder. Now, $V_{14}$ might be high when the value of being the unique leader with double capacity compared to the opponents is considered as high. $V_{33}$ is high, when the third bidder is willing to pay a lot for reaching the capacity of the two leading firms. Both cases are, of course, plausible.

One may object that $V_{33}$ must have been low because the third bidder had already reduced his bidding rights. However, as we argued above, straightforward bidding is generally not optimal behavior for the third bidder either. Therefore, it is quite plausible that the third bidder had an incentive to reduce demand before prices reached the level of his marginal valuation. This is in particular the case when the third bidder thinks that a market size of four cannot be reached.

\section{Merit of the German Auction Design}

Should future spectrum auction designers borrow some key ingredients of the design employed in the German UMTS auction? ${ }^{13}$

While one may debate whether the German regulator should have assured at least one new entry into the mobile phone market, the idea of allowing some flexibility by letting bidders aggregate their own licenses, is appealing. Indeed, starting from the English style rules, which broke down the available $60 \mathrm{MHz}$ of paired spectrum into 5 fixed licenses in

\footnotetext{
${ }^{13}$ For a detailed discussion of the deficiencies of the English auction design, and a number of further recommendation for changing spectrum auction rules, see WoLFSTETTER [2001]. For a very careful critical assessment of the English auction design, and some puzzling features of actual bidding in the English auction, see BöRGERS AND DUSTMANN [2001].
} 
the UK, it might have been better to break down the available supply into individual blocks, and allow bidders to aggregate these blocks into either 5 or 6 licenses. By thus borrowing from the German auction rules, the British would have assured at least five licenses, and yet reached more competition or more revenue.

A defendant of the English rules might respond that revenue cannot be lower if one excludes that flexibility and sticks to the English rules. For, if the German style rules lead to 6 licenses, revenue must be lower (bidders prefer a market of 5 licenses to one of 6), whereas if it results in only 5 licenses, revenue should be just the same as in the English design. Therefore, one is lead to conclude that allowing bidders to aggregate spectrum into either 5 or 6 licenses, in the spirit of the German design, may give rise to more competition but never to more revenue (and certainly never more competition and more revenue).

However, this argument misses one important point: It assumes that bidder participation is the same under both rules, and that there are more bidders than licenses. Once bidders know the ranking of their valuations, which they did after the battle for the pan-European field was settled, low ranking bidders know that they will always be outbid in an open ascending auction, and therefore do not even bother to participate. This suggests that the English design poses a serious bidder participation problem: as a tendency, the number of participating bidders converges to the number of licenses, as it did occur in Switzerland (see Table 1), and thereafter in Belgium and in Israel (where the auction was subsequently called off).

Competition is not a free good; in order to participate, bidders must have some reasonable chance of obtaining a license. The flexibility offered by the German style auction design does offer such an incentive. If it is effective and raises bidder participation, the German style auction design may, paradoxically, give rise to more competition and more revenue.

The two last UMTS auctions in the year 2000, in Austria and Switzerland, are a case in point. Austria employed the German and Switzerland the English design. The enthusiasm of the market concerning the prospects of the UMTS technology had already cooled off, and the main battles for the pan-European field were already settled. Nevertheless, the performance was quite different. After the usual "bidder meltdown", in Austria 6 bidders showed up to bid for 4-6 licenses; whereas in Switzerland 4 bidders showed up to bid for 4 licenses; exactly as one would expect it to occur, after bidders know their ranking of valuations. In the end, both auctions earned relatively low revenues, however, Austria achieved considerably more competition (3 vs. 1 new entries), and more revenue (see Table 1).

Another interesting feature of the German auction was the sale of "ab- 
stract" spectrum, already mentioned in Section 2. In principle, this may eliminate the coordination problems that plagued earlier spectrum auctions in the US. However, while this worked well in the 1999 German GSM auction, it was apparently not as successful in the German UMTS auction. Indeed, one year after the auction, the regulator and license holders have not yet reached an agreement on the allocation of concrete spectrum.

However, in one regard, the German design was unnecessarily complicated. Instead of asking for bids on the numbered abstract licenses, it would have been better to employ an "ascending price clock auction" format. There, the auctioneer announces a uniform price per block, and asks bidders to state their demand at that unit price. If demand is equal to or below the given supply, the auction ends, and bidders get what they demanded at that price; whereas if demand exceeds supply, the unit price is raised by one increment, and the procedure is repeated. This format would have eliminated bidder coordination problems. Moreover, there would have been no need for the "at least two" restriction, because in that auction format no bidder is ever left with just one spectrum block, unless he finds it profitable to operate with one block.

\section{Conclusions}

In the present paper we explained the rules of the German UMTS auction, and proposed a rational reconstruction of the observed play. Our results suggest that the outcome of that auction is not at all bizarre, contrary to what some of the critics of the German auction design have claimed. Moreover, we could not confirm the critics' other contention, that the auction design used in Germany is inferior to that used in England and in most other European countries. On the contrary, we pointed out that the design used in Germany tends to give rise to more competition or more revenue than the competing English design, which indeed it did in the European spectrum auctions in the year 2000. This suggests that the designers of future spectrum auctions may be well advised to borrow some ingredients of that design.

At the same time, we would like to stress that the design of good spectrum auction mechanisms is still subject to many open questions. Neither the English nor the German design is geared to achieve efficiency in the sense of maximizing the weighted sum of consumer and producer surplus; our understanding of multi-unit auctions is still insufficient; and the design of optimal mechanisms that implement an efficient market structure is still in its infancy. ${ }^{14}$ Moreover, bidder participation will remain a concern, even if one alleviates it by introducing the kind of 
flexibility in the aggregation of licenses that was used in Germany. In this regard, a major improvement can only be expected if one replaces the auctioning of the portions of the radio spectrum set aside for mobile telecommunication by auctioning the entire radio spectrum in one auction.

\section{References}

AURIOL, E. AND J. LAFFONT [1992], "Regulation by duopoly," Journal of Economics and Management Strategy, 1, 507-533.

AUSUBEL, L. AND J. SCHWARTZ [1999], “The ascending auction paradox,” Working paper, University of Maryland.

BÖRGERS, T. AND C. DUSTMANN [2001], "Strange bids: Bidding behavior in the United Kingdom's third generation spectrum auction,” Discussion paper, University College, London.

DANA, J. D. AND K. E. SPIER [1994], “Designing a private industry,” Journal of Public Economics, 53, 127-147.

ENGELBRECHT-WIGGANS, R. AND C. KAHN [1998], "Low revenue equilibria in simultaneous auctions," Working paper, University of Illinois.

GRIMM, V., F. RiEDEL, AND E. WOLFSTETTER [2000], “Implementing efficient market structure,” Working paper, Humboldt University at Berlin.

- [2001], "Low price equilibrium in multi-unit auctions: The GSM spectrum auction in Germany," Working paper, Humboldt University at Berlin.

JeHIEL, P. AND B. MoldovAnU [2000], "A critique of the planned rules for the German UMTS/IMT-2000 license auction,” Working paper, University of Mannheim.

- [2001], “The European UMTS/IMT-2000 license auctions,” Discussion paper, University of Mannheim.

Klemperer, P. [2001], "Collusion and predation in auction markets," Working paper, Nuffield College, Oxford University.

MENEZES, F. M. [1996], “Multiple-unit English auctions,” European Journal of Political Economy, 12, 671-684.

\footnotetext{
${ }^{14}$ Some first contributions in this direction, in the optimal mechanism design tradition, are DANA AND SPIER [1994], AURIOL AND LAFFONT [1992], and GRIMM, RIEDEL, AND WOLFSTETTER [2000].
} 
Moldovanu, B. [2000a], "Für ein Plätzchen am Himmel der Funker," Frankfurter Allgemeine Zeitung, p. 29.07.2000.

- [2000b], "Kleiner Verfahrensfehler mit großen Folgen," Financial Times Deutschland, p. 04.06.2000.

REGTP [2000], "Entscheidung der Präsidentenkammer vom 18. 02. 2000 über die Regeln für die Durchführung des Versteigerungsverfahrens zur Vergabe von Lizensen für UMTS/IMT-2000; Mobilkommunikation der dritten Generation," Official document, Aktenzeichen: BK-1b98/005-2, http://www.regtp.de.

WEBER, R. J. [1983], “Multiple-object auctions," in: R. EngelbrechtWiggans, M. Shubik, and J. Stark (eds.), "Auctions, Bidding, and Contracting," pp. 165-191, New York University Press, New York.

WOLFSTETTER, E. [2001], "The Swiss UMTS spectrum auction flop: Bad luck or bad design?” Working paper, Humboldt Universität zu Berlin. 